\title{
Foreword to the American Edition
}

This book treats a series of questions that concern all of mankind. To what do we owe our faculty of reason - that power of thought in which we take so much pride, and which philosophers since Aristotle have considered to be uniquely human? Is rationality equally distributed among all peoples? Was it inborn in us from the beginnings of our existence on earth, or did it first blossom only with the invention of two things for which the Western world is pleased to take credit: democracy and philosophy? Did it, in either case, subsequently achieve its fullest flowering as a consequence of modern advances in science and technology? If it did, must we say that instrumental rationality - the ability to relate ends to means that is peculiar to Homo aconomicus - represents the unsurpassable culmination of human reason? Or is it merely a degraded and inadequate facsimile?

Whether reason is innate or acquired, we know that it can be lost, individually and collectively. But what does this tell us about the nature of reason? Not only the murderous rages, the genocides and the holocausts, but also the folly that leads humanity to destroy the conditions necessary to its survival — what do these things teach us about the absence of reason? In I797, Francisco Goya made an etching to which he gave the title Elsueño de la razón produce monstruos. It shows a man fallen asleep in his chair, his head resting heavily on a table, surrounded by terrifying creatures of the night, owls and bats. A large cat looks on. With this arresting image an artist who had upheld the ideals of the French Revolution in opposition to many of his countrymen expressed his horror at the awful massacres of the Terror. The title is generally translated as "The Sleep of Reason Produces Monsters." But the Spanish word sueño, as it happens, may mean either sleep or dream. In this second sense Goya's title acquires a much more disturbing meaning. It is not the eclipse of reason that produces monsters; 
on the contrary, it is the power of reason to dream, to fantasize, to have nightmares-to unleash the demons of the imagination.

To all these questions there is a simple reply, or at least a reply that is simply stated: reason, like all human institutions, has its source in religion. It is the same answer one finds in the French tradition of social science inaugurated by Émile Durkheim and Marcel Mauss. Durkheim, in his great work The Elementary Forms of Religious Life, congratulated himself on having established that "the fundamental categories of thought, and therefore of science, have religious origins." As a result, he concluded, "it can be said that nearly all great social institutions are derived from religion." If Durkheim was right, as I believe he was, the adventures and misadventures of human reason will make no sense to us unless we examine them in the light of his discovery.

Even though the topics I discuss in this book are of universal importance, the conclusions I draw cannot help but arouse sharply differing reactions among my readers, depending in large part on the place of religion in public life that they are accustomed to regard as proper. In the Western world, probably no two countries are separated by a greater distance with regard to the place reserved for religion than the United States and France, as Alexis de Tocqueville was perhaps the first to point out when he traveled through America in the I830s. The gap between them is hardly smaller today than it was in Tocqueville's time. It may be well, then, to say a few words at the outset in the hope of preventing at least the grossest misunderstandings.

France is proud to describe itself as a secular country. It is telling that the meaning of the phrase pays laïc cannot easily be conveyed in English. Secularism in the French sense does not signify the neutrality of the state, as it does in America. The doctrine of the neutrality of the state, due to classical liberalism, assumes that the state is incompetent to decide what constitutes the good life, and therefore cannot take sides between competing conceptions. In France, by contrast, secularism is understood to be a fundamentally anti-liberal and "perfectionist" concept. On this view, the state has both the authority to say in what the

I. Émile Durkheim, Les formes élémentaires de la vie religieuse, 6th ed. (Paris: Presses universitaires de France, 1979), 598. 
good life consists and the right to command obedience to its will in the public sphere. It is here that the problem of religion makes itself felt most acutely. The republican tradition in France makes conformity to reason the sole qualification for taking part in public life. Condorcet expressed the idea beautifully: "Generous friends of equality, of liberty, unite to demand from your governors an education that will make reason the property of the people." 2 Thus the ideal of the French Revolution-rationality as the highest public virtue.

Now, to the French secular mind, religious faith of every kind seems profoundly irrational. Religion and its visible signs therefore have no legitimate place in the public sphere in France, where education is obligatory and free of charge for all. The thought of a president of the republic taking the oath of office on a Bible is unimaginable. Were the president to conclude his inaugural address with the words "God save France," there would be rioting in the streets. When the nation's currency was the French franc, the idea that banknotes might bear the legend "In God We Trust" would have been simply inconceivable. These commonplaces of American political culture are deeply shocking to my fellow citoyens, no less shocking than the recent French law prohibiting the display of emblems of religious affiliation in schools, whether the Islamic veil, the Jewish skullcap, or Christian crucifixes greater than a certain size, seems to many of my American friends. For someone like myself, who loves both countries, this mutual incomprehension is disheartening.

Tocqueville was forcibly struck above all by the religious faith of the American people. Having come to America to study democracy, he came afterward to think that the former was the necessary condition of the latter. As he so memorably put it, "I doubt whether any man can endure, at one and the same time, complete religious independence and complete political freedom; and I am led to believe that, if a man is without faith, he must serve another, and, if he is free, he must believe."3 Some of the most eminent political philosophers in France today have strongly

2. Marie Jean Antoine Nicolas de Caritat, marquis de Condorcet, Cinq mémoires sur l'instruction publique (179I), ed. Charles Coutel and Catherine Kintzler (Paris: Garnier-Flammarion, 1994), I04.

3. Alexis de Tocqueville, De la démocratie en Amérique, vol. 2 (I840), I.5 (Paris: Garnier-Flammarion, 198I), 31. 
criticized Tocqueville on this point. ${ }^{4}$ The true spirit of democracy, they say, was there to be found in his own country, post-revolutionary France. A democratic society is not one that is in harmony with its basic principles, as American theorists such as John Rawls have maintained. Just the opposite is true: it is one in which these principles are perpetually called into question, a social and political regime marked by conflict and division over the very values on which it is founded; indeed, it is of the essence of democracy that such questioning should be constant and open-ended. In Tocqueville's time, France was torn between those who favored democracy and those who opposed it. This very tension, it is said, worked to strengthen democracy. French political thought today, or at least its most secular element, therefore concludes it is futile to suppose, as Tocqueville did, that religion can erect a durable barrier against the subversive influences that erode the foundations it has given itself. God and religion will inevitably perish as a result of the growth of democracy.

In America, the growth of religious fundamentalism in recent decades, and the excesses to which it has given rise, have produced by way of reaction an assault against religion in which God has become, or become once more, the perfect scapegoat — and all the more perfect as he is believed not to exist. The titles of bestsellers that line the shelves of American bookstores-The God Delusion, God Is Not Great, The End of Faith, Breaking the Spell-do not deal in nuance. Together, they amount to a declaration of war against the religious foundations of American democracy.

It is tempting to imagine that the secular crusade of the French Left and the anti-religious crusade of the American Left are somehow similar. And yet they have nothing in common. Few books by religion-bashers in England and America are translated into French. The ones that are sell poorly, and their ideas have no resonance whatever in the quarrels over secularism that regularly enliven French political debate. There are two reasons for this. The first is that scholars and intellectuals in France have a hard time taking seriously what they consider to be the work of mere pamphleteers, whose outstanding characteristics are, on the one hand, a lack of culture, and, on the other, a weakness for arguments that rely on

4. See, e.g., Marcel Gauchet's essay on Tocqueville in Mark Lilla, ed., New French Thought: Political Philosophy (Princeton, N.J.: Princeton University Press, 1994), 9I-III. 
biological theories of evolution and research in the cognitive sciences. But this is nothing new. Attempts to reduce social phenomena and the symbolic dimension of human existence to purely natural causes have never gotten a warm welcome in France.

The second reason has to do with the history and sociology of religion, which, it must be admitted, is not the strong point of the new atheists in England and America. One often has the impression that they take particular delight in making Christianity out to be no less irrational than any other religion, and therefore one more reason for dismissing religion in all its forms. French thinkers from Durkheim onward, by contrast, deepening an insight famously associated with Max Weber, have argued that secularization-what Weber called the disenchantment of the world-was a paradoxical consequence of the spread of Christian faith that, in its turn, prepared the way for the flourishing of economic rationality. Indeed, it is not uncommon today to hear Christianity described as "the religion of the end of religion." The blindness of the new atheists to the fundamentally distinctive nature of Christianity is taken in France to disqualify them from taking part in the debate about the nature of religion and its future.

I mention all these things here in order to remind my American readers that one can hardly write a book on the religious origins of human reason without taking into account the settled prejudices of one's audience. Nevertheless, in the pages that follow, I touch only in passing on questions that are primarily of interest to historians and sociologists of religion. I concentrate on a different set of questions, philosophical questions, which are logically prior to the ones that concern historians and sociologists. I begin by considering a notion that lay at the heart of religious anthropology when it was still recognized as a discipline in its own right, namely, the sacred. I do not dispute the vagueness of this concept, nor do I try to give an exhaustive account of what it involves. Instead I characterize its formal properties, and go on to show that human reason preserves the mark of its origins in the sacred, however much it may regret this fact. I then take up in turn several related kinds of rationality in which the mark of the sacred may yet be plainly seen, in science, politics, economics, and strategic thought.

Along the way I develop three lines of argument: first, that the Judeo-Christian tradition cannot be identified with the sacred, since it 
is responsible for the ongoing desacralization (or disenchantment) of the world that epitomizes modernity; second, that desacralization threatens to leave us defenseless against our own violence by unchaining technology, so that unlimitedness begins little by little to replace limitedness; third, the greatest paradox of all, that in order to preserve the power of self-limitation, without which no human society can sustain itself and survive, we are obliged to rely on our own freedom. It will be clear, I think, from what I have already said about the differences between France and America, that in making these claims I come directly into conflict with both French secularists and American religion-bashers, since they all consider religion to be the height of irrationality, whereas they themselves adamantly believe in Reason, pure and immaculate; with religion-bashers, in particular, since they fail to see what even secularists accept, namely, that Christianity has been the driving force in bringing about the secularization of society; with secularists, in particular, since they fail to see that reason in its various forms continues still today to display the mark of the sacred; and, of course, with religious fundamentalists of all faiths, since they resemble their rationalist adversaries in regarding reason and the sacred as strangers to each other, locked together in a merciless struggle to the death. That's a lot of people to take on at once.

One last thing. The task of bringing over not only my words, but the intricate structure of my arguments and their subtlest shades of meaning, from the language and culture of France to the language and culture of America has required a translator of exceptional talent. Once again I am pleased to be able to give my warmest thanks to Malcolm DeBevoise.

Paris, December 2012 
THE MARK OF THE SACRED 
